Article

\title{
Examining the Association of Socioeconomic Position with Microcephaly and Delayed Childhood Neurodevelopment among Children with Prenatal Zika Virus Exposure
}

\author{
Grace M. Power 1,2,3 ${ }^{\text {D }}$, Suzanna C. Francis ${ }^{2}$, Nuria Sanchez Clemente ${ }^{2,4}$, Zilton Vasconcelos ${ }^{4}$, \\ Patricia Brasil ${ }^{4}$ (D), Karin Nielsen-Saines ${ }^{5}$, Elizabeth B. Brickley ${ }^{2, *(D)}$ and Maria E. Moreira ${ }^{4, *}$ \\ 1 Department of Disease Control, Faculty of Infectious and Tropical Diseases, London School of \\ Hygiene \& Tropical Medicine, London WC1E 7HT, UK; grace.power@bristol.ac.uk \\ 2 Department of Infectious Disease Epidemiology, London School of Hygiene \& Tropical Medicine, \\ London WC1E 7HT, UK; suzanna.francis@lshtm.ac.uk (S.C.F.); nuria.sanchez-clemente@lshtm.ac.uk (N.S.C.) \\ 3 MRC Integrative Epidemiology Unit, Population Health Sciences, Bristol Medical School, \\ University of Bristol, Bristol BS8 2BN, UK \\ 4 Fundação Oswaldo Cruz, Rio de Janeiro 21040-900, Brazil; zilton.vasconcelos@iff.fiocruz.br (Z.V.); \\ patricia.brasil33@gmail.com (P.B.) \\ 5 Pediatrics, University of California, Los Angeles, CA 90095, USA; knielsen@mednet.ucla.edu \\ * Correspondence: elizabeth.brickley@lshtm.ac.uk (E.B.B.); bebeth@iff.fiocruz.br (M.E.M.)
}

Received: 30 September 2020; Accepted: 20 November 2020; Published: 23 November 2020

\begin{abstract}
Increased rates of Zika virus have been identified in economically deprived areas in Brazil at the population level; yet, the implications of the interaction between socioeconomic position and prenatal Zika virus exposure on adverse neurodevelopmental outcomes remains insufficiently evaluated at the individual level. Using data collected between September 2015 and September 2019 from 163 children with qRT-PCR and/or IgM-confirmed prenatal exposure to Zika virus participating in a prospective cohort study in Rio de Janeiro, Brazil (NCT03255369), this study evaluated the relationships of socioeconomic indicators with microcephaly at birth and Bayley-III neurodevelopmental scores during the early life course. Adjusted logistic regression models indicated increased odds of microcephaly in children born to families with lower household income (OR, 95\% CI: 3.85, 1.43 to 10.37) and higher household crowding (OR, 95\% CI: 1.83, 1.16 to 2.91), while maternal secondary and higher education appeared to have a protective effect for microcephaly compared to primary education (OR, $95 \%$ CI: $0.33,0.11$ to 0.98 and $0.10,0.03$ to 0.36 , respectively). Consistent with these findings, adjusted linear regression models indicated lower composite language $(-10.78,95 \%$ CI: -19.87 to -1.69$)$, motor $(-10.45,95 \%$ CI: -19.22 to -1.69$)$, and cognitive ( -17.20 , 95\% CI: -26.13 to -8.28$)$ scores in children whose families participated in the Bolsa Família social protection programme. As such, the results from this investigation further emphasise the detrimental effects of childhood disadvantage on human health and development by providing novel evidence on the link between individual level socioeconomic indicators and microcephaly and delayed early life neurodevelopment following prenatal Zika virus exposure.
\end{abstract}

Keywords: Zika virus; congenital Zika syndrome; microcephaly; neurodevelopment; socioeconomic position; health equity

\section{Introduction}

Zika virus (ZIKV) is a mosquito-borne flavivirus [1,2], principally transmitted by the Aedes aegypti vector. Ae. aegypti is an anthropophilic mosquito species with a high daily survival rate, capable 
of facilitating explosive arboviral epidemics in urban settings [3]. Vertical transmission of ZIKV during pregnancy has been associated with adverse developmental consequences in infected offspring, including microcephaly and other neurological impairments, which are collectively recognised as congenital Zika syndrome (CZS) [4].

Studies have demonstrated increased frequencies of ZIKV infection and CZS in economically deprived areas of Brazil at the population level $[5,6]$. While these studies play an important role in assessing the association between ZIKV and social conditions, the existing evidence base relies on ecological study designs with a geographically defined group as the unit of observation. Not only is ecological fallacy a potential limitation for interpreting associations, but socioeconomic risk factors at the individual level remain insufficiently identified and evaluated. In addition to congenital ZIKV infection, socioeconomic position (SEP) may also influence neurodevelopment. Children typically experience poorer health and developmental outcomes with higher levels of disadvantage [7]. Risk factors for cognitive and socioemotional developmental delays have been shown to include nutrient deficiencies and social and economic deprivation, whilst known protective factors comprise breastfeeding and maternal education [8].

This study investigates the associations between socioeconomic factors and two outcomes, microcephaly and neurodevelopmental delays, in a cohort of 163 infants with in utero ZIKV exposure, in the State of Rio de Janeiro, Brazil. We hypothesise that there may be a relationship between measures indicative of lower SEP and adverse neurodevelopmental outcomes among infants with prenatal exposure to ZIKV. A better understanding of the most at-risk groups in the event of a future ZIKV outbreak could help to drive policy solutions that encourage more targeted approaches to public health interventions aimed at reducing health and developmental inequities.

\section{Materials and Methods}

A prospective cohort study (ZIKAIFF) was conducted between September 2015 and September 2019 at Instituto Nacional de Saúde da Mulher, da Criança e do Adolescente Fernandes Figueira (IFF/Fiocruz), a reference hospital for women, children and adolescents in Rio de Janeiro, Brazil. Mothers of children in the cohort provided informed written consent for their children to participate. Local ethical approval was obtained for the protocol of the original cohort study titled "Exposição Vertical ao Zika Virus e suas conseqüências no neurodesenvolvimento da criança/Vertical Exposure to Zika Virus and Its Consequences for Child Neurodevelopment: Cohort Study in Fiocruz/IFF" by the Oswaldo Cruz Foundation (Fiocruz), Rio de Janeiro, Brazil (Plataforma Brasil, CAAE: 52675616.0.0000.5269 and registered in ClinicalTrials.gov (NCT03255369). Ethical approval for this project was granted on 10 May 2019 by the London School of Hygiene \& Tropical Medicine MSc Research Ethics Committee (Ref: 15951).

\subsection{Study Population}

Participants in the ZIKAIFF cohort comprised children born between February 2016 and September 2017 [9], in the State of Rio de Janeiro, Brazil. The cohort included children with suspected prenatal ZIKV exposure, identified from two key sources: (i) those born to symptomatic women presenting with rash during pregnancy and (ii) those born to women referred to IFF/Fiocruz due to foetal abnormalities during pregnancy detected through ultrasound screening.

The present investigation was limited to the 163 livebirths (55.1\%; 163/296 of the full cohort) with lab-confirmed prenatal exposure to ZIKV that participated in infant clinical assessment at birth, and if normocephalic, at least one subsequent neurodevelopmental evaluation with the Bayley-III instrument. For this analysis, in utero ZIKV exposure was confirmed through either (i) the detection of ZIKV RNA by qRT-PCR testing of maternal serum, urine, amniotic fluid, breast milk, and/or placenta samples or neonatal serum, urine and cerebrospinal fluid sample [10] or (ii) through the detection of IgM in neonatal serum samples using the Centers for Disease Control and Prevention (CDC) Zika IgM antibody capture enzyme-linked immunosorbent assay (MAC-ELISA) [11]. 


\subsection{Exposures}

Several primary exposures were investigated as potential socioeconomic risk markers at the individual level. These included maternal educational level (partial/completed higher, secondary or primary school education), maternal race/ethnicity (White Brazilians, mixed-race Afro-Brazilians, Black Afro-Brazilians and East Asian Brazilians), household monthly income (relative to the 2019 minimum wage of BRL998) (Classes A, B, C and D: $>2 \times$ minimum wage and Class E: $<2 \times$ minimum wage), household participation in the Bolsa Família conditional cash transfer social protection program (yes or no) and household crowding index (individuals in the house/bedrooms in the house), obtained from parent-reported data through survey questionnaires given to caregivers by clinical staff at IFF/Fiocruz in Rio de Janeiro, Brazil, upon enrolment in the cohort.

\subsection{Outcomes}

\subsubsection{Infant Clinical Assessments}

The outcome variable of microcephaly was defined as a head circumference $\mathrm{Z}$ score of more than two standard deviations (SD) below the mean for gestational age and sex, consistent with the latest Brazilian Ministry of Health's case definition. Head circumference measurements were taken from all live newborns and evaluated using the INTERGROWTH-21st Global Perinatal Package [12]. All evaluations took place at IFF/Fiocruz in Rio de Janeiro, Brazil by paediatric specialists at birth.

\subsubsection{Neurological Evaluations}

Bayley-III assessments were offered to all normocephalic children. Bayley-III assessments of children born with microcephaly were not routinely undertaken as the functional challenges faced by children in this group precluded further assessment of developmental milestones using this instrument $[13,14]$. Bayley-III is an internationally accepted instrument used to assess the development of infants and young children aged between 1 and 42 months. The assessment and training materials have been translated into Brazilian Portuguese and validated for use in Brazil [15].

The Bayley-III scales derive a developmental quotient by evaluating three domains: the language scale, which assesses expressive and receptive language; the motor scale, which assesses fine and gross motor skills; and the cognitive scale [16]. Composite scores were obtained for each subset to determine performance compared with the normative population and presented as a continuous variable. They were scaled to a metric, with a mean of 100, SD of 15 and range of 40 to 160. Developmental delay was defined as "at risk" if performance was between 1 and 2 SD below the mean (i.e., a score of 70-85) and "severely delayed" if the score was more than 2 SD below the mean (i.e., a score $<70$ ).

For children who underwent repeated evaluations, the Bayley-III scores obtained at the oldest age were used in the current analysis. Assessments took place at IFF/Fiocruz and were performed by trained psychologists.

\subsection{Additional Covariates}

Further potential confounders and effect modifiers were considered and integrated into conceptual hierarchical frameworks (Figure 1). These were derived from the literature and through conversations with clinical staff at IFF/Fiocruz [17].

Since being a recipient of $\mathrm{BF}$ is conditional on having a low-income as well as school attendance, health monitoring and prenatal care attendance, household participation in BF was not considered a confounder when household income was the main exposure, as it was assumed on the causal pathway [18]. The variables indicating smoking, drug-taking and occupational exposure to toxic products during pregnancy, which may be influenced by SEP, were assumed on the causal pathway between SEP indicators and both outcome measures. Moderate exposure to maternal smoking, drug-taking and toxic products can impact foetal brain development and may consequently be risk 
factors for microcephaly and neurodevelopmental delays [19] and thus were not included in the multivariable analyses.

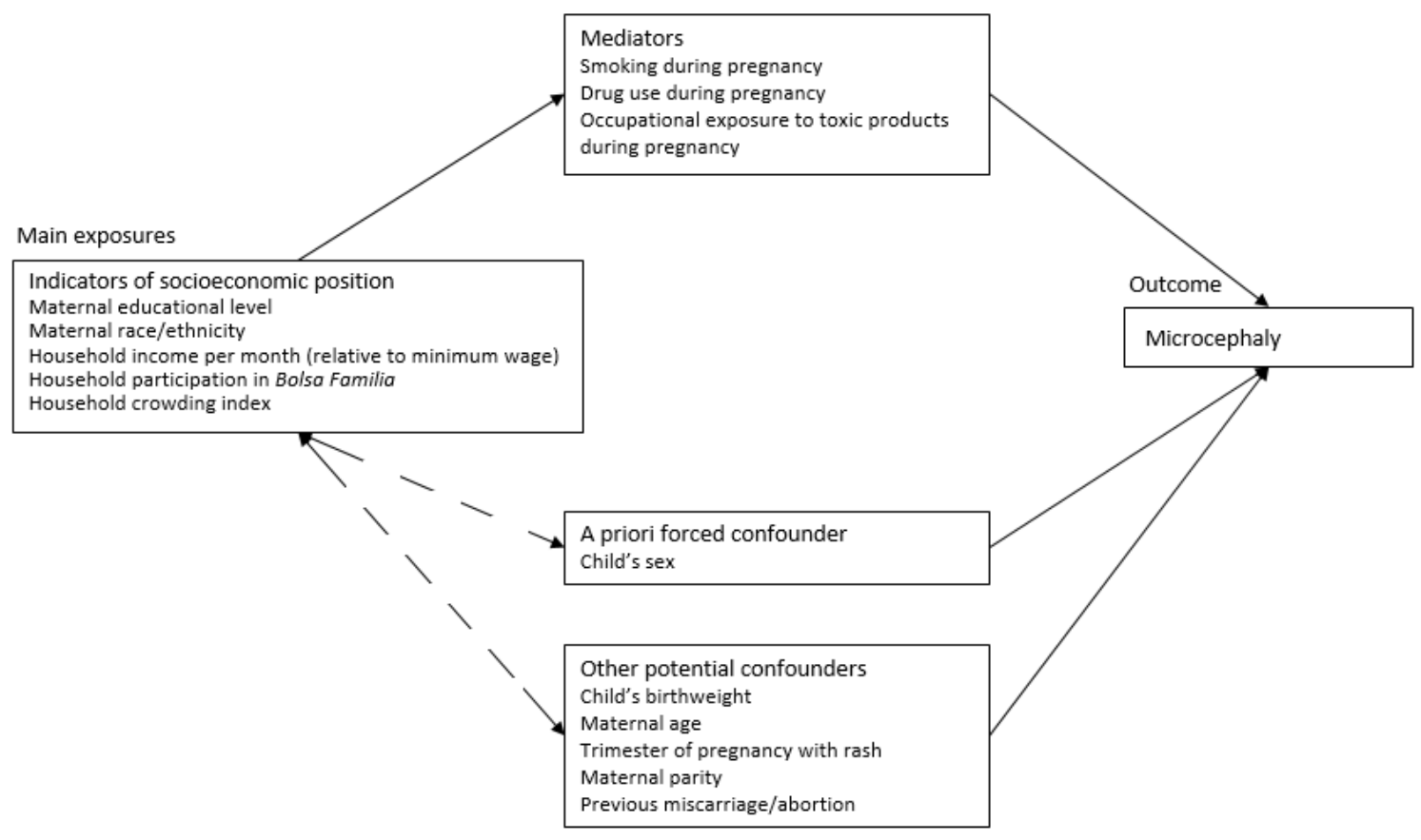

(a)

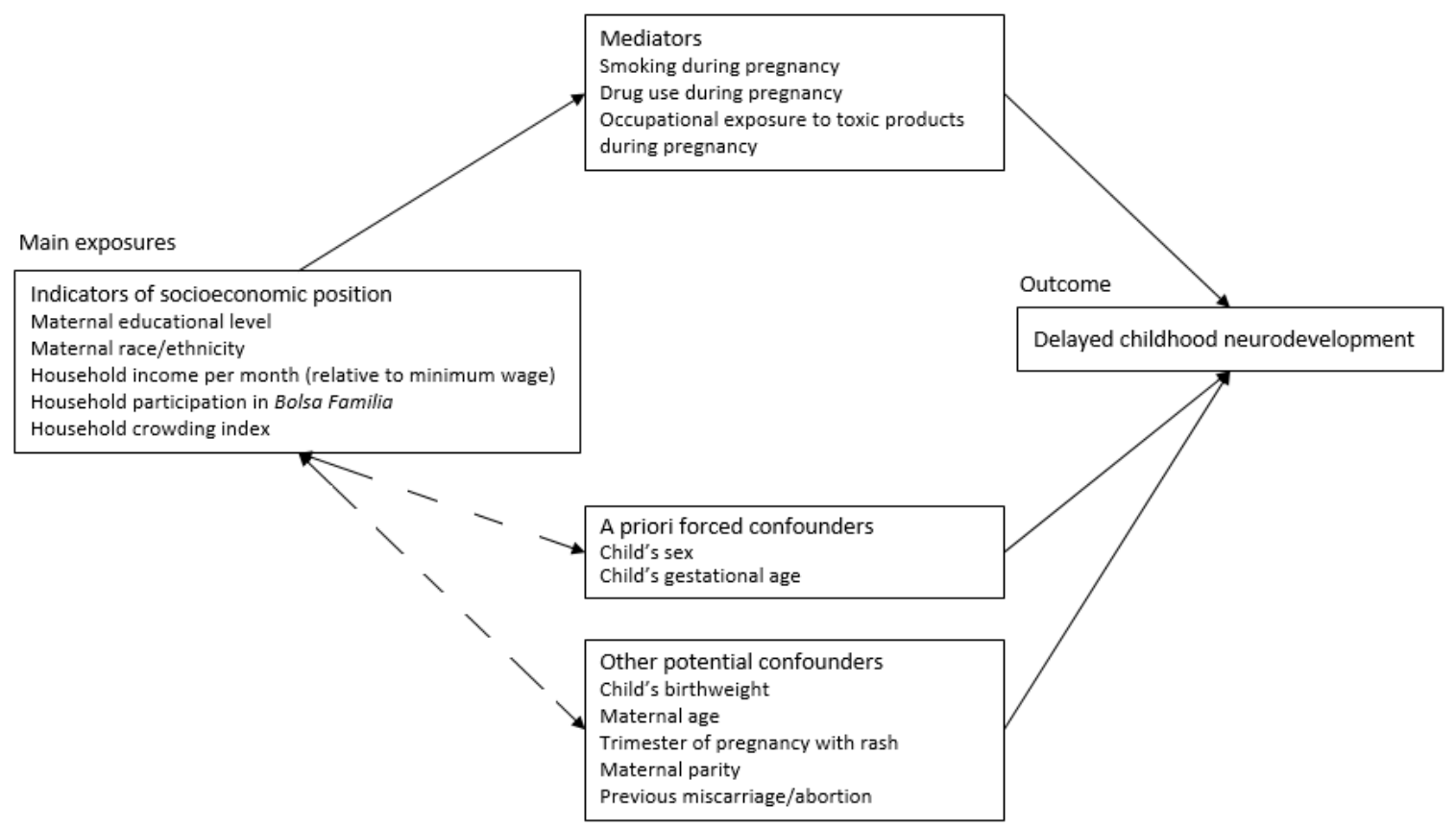

(b)

Figure 1. Conceptual frameworks for the association between the exposures of interest; social determinants and the outcomes; microcephaly (a) and delayed neurodevelopment (b) following in utero exposure to ZIKV. 


\subsection{Data Cleaning and Missing Values}

Data entry errors were checked as part of the quality assessment. Duplicates were removed and outliers queried and rectified at the study site. Missing data were explored and missingness patterns investigated (Table A1). The complete-case analysis was employed in final multivariable models.

\subsection{Statistical Analysis}

Multivariate regression analyses were conducted (logistic models for assessing microcephaly and linear models for the three continuous composite Bayley-III score outcomes: language, motor and cognitive). The variable indicating child's sex was a priori forced into each of the multivariate models. Gestational age was a priori forced into multivariate linear models for continuous Bayley-III score outcomes.

Conceptual hierarchical frameworks aided in the determination of mediators and confounders when fitting models. To estimate the effect of individual level SEP risk factors on the odds of microcephaly, a forward selection approach was used. Primary exposure variables indicating SEP were used to initiate each model with the forced variables that were a priori determined. Potential confounders, including SEP variables that were not considered the main exposure of interest in that particular model, were then built into each model according to how much their inclusion in the model changed the effect estimate for the main exposure. Variables were added to models only if they changed the effect estimate by more than $10 \%$. To avoid problems of data sparsity, models contained no more than five parameters, since there were 51 events of microcephaly. Multiple linear regression models were then fitted for each of the composite Bayley-III score outcomes with SEP exposure variables, the forced variables selected a priori and the strongest potential confounding variables, ensuring that there were at least five observations for each variable added to the model to mitigate sparse data bias. To assess consistency regarding direction and magnitude of estimates, sensitivity analyses were performed using data with participants with suspected prenatal exposure to ZIKV who did not have qRT-PCR or IgM confirmation. This dataset was larger $(n=286)$ and had 91 microcephaly cases. Data analysis was performed in Stata, version 13.0 (StataCorp., College Station, TX, USA)

\section{Results}

Of the 296 maternal-child dyads enrolled in the ZIKAIFF cohort, 256 (86.5\%; 256/296) were qRT-PCR or IgM laboratory tested and $202(68.2 \%$; 202/296) had qRT-PCR $(85.6 \%$; 173/202) or IgM (36.1\%; 73/202) confirmation for ZIKV. Of the confirmed cases, eight $(4.0 \% ; 8 / 202)$ of the children died prior to outcome ascertainment and $31(15.3 \% ; 31 / 202)$ of the normocephalic children were lost to follow-up. In total, 163 (55.1\%; 163/296) participants of the total cohort were included in the final study sample (Figure 2).

The study sample comprised 84 (51.5\%) females and 79 males (48.5\%). Fifty-one (31.3\%) had microcephaly at birth and 112 were normocephalic at birth. Children born with a normal head circumference were followed up with their last Bayley-III neurodevelopmental assessment performed at a median (IQR) age of 19.6 months (range: 4.9 to 40.1 months). The median (IQR) gestational age at delivery was 38 weeks (38-40 weeks) and birthweight was $3060 \mathrm{~g}$ (2675-3420 g). In total, 18.4\% $(30 / 163)$ had low birthweight $(<2500 \mathrm{~g})$. Mothers were aged between 17 and 43 years and lived in the State of Rio de Janeiro, Brazil at the time of enrolment. Amongst those with data collected on maternal education, $15.0 \%(22 / 147)$ of children were born to mothers with up to primary school education, $52.4 \%$ (77/147) with some or completed secondary school education and 32.7\% (48/147) with some or completed higher education. Furthermore, 36.6\% were (53/145) White Brazilians, $45.5 \%$ (66/145) mixed-race Afro-Brazilians, 15.9\% (23/145) Black Afro-Brazilians and 2.1\% (3/145) East Asian Brazilians. Over half of the participants were in Social Class E, receiving $<2 \times$ minimum wage $(50.8 \% ; 67 / 132)$. In total, $19.6 \%$ (27/138) of the study population were recipients of Bolsa Família (Table 1). 


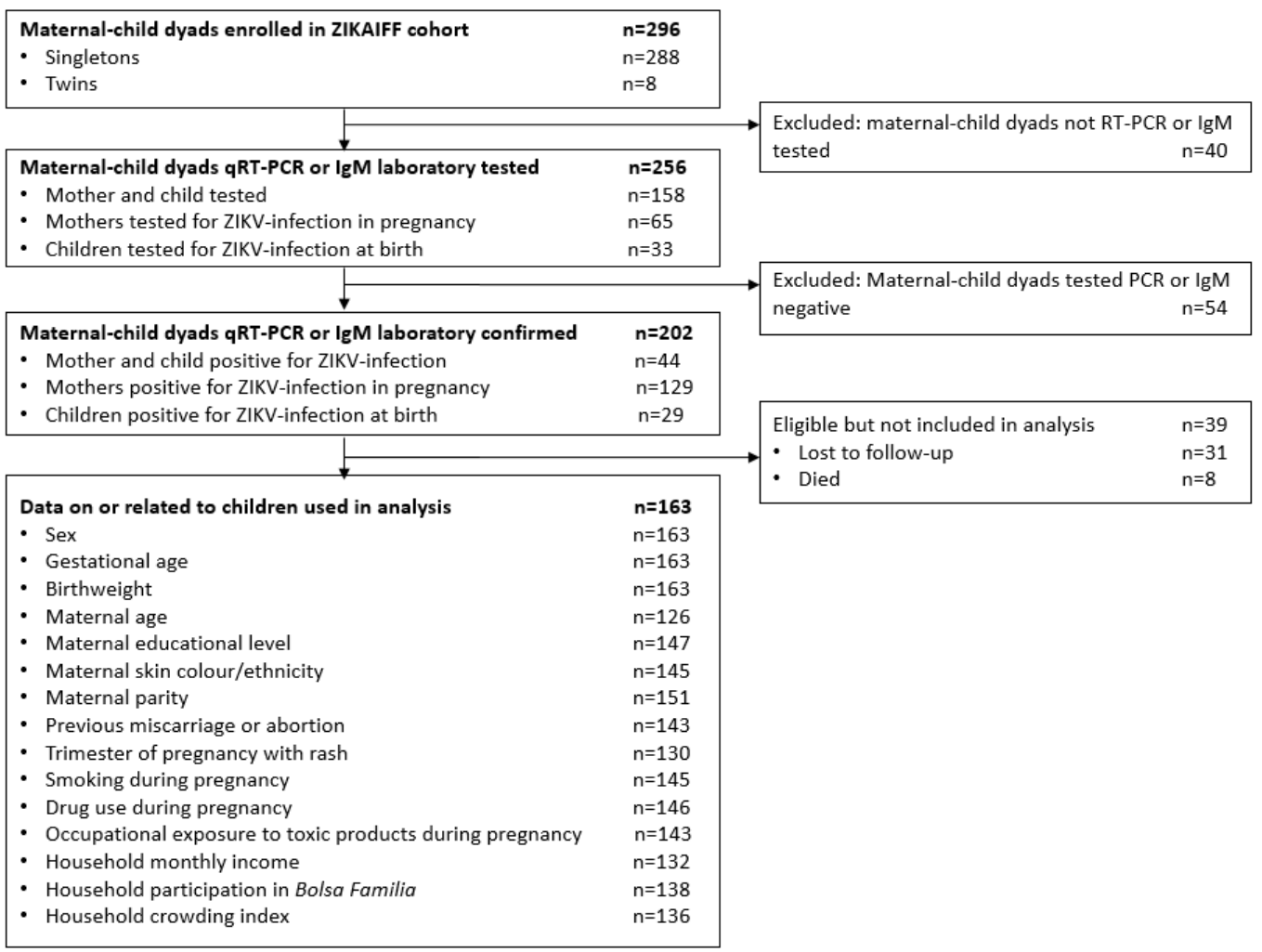

Figure 2. Flow diagram for cohort selection based on study inclusion and exclusion criteria.

There was a mean composite language score of $90.3(\mathrm{SD} \pm 13.1)$, minimum and maximum of 47 and 115, a mean composite motor score $95.3(\mathrm{SD} \pm 12.4$ ), minimum and maximum of 50 and 124 and a mean composite cognitive score of 102.8 (SD \pm 13.5$)$, minimum and maximum of 65 and 145 (Figure 3). Among the 112 children with Bayley-III results, 25.9\% (29/112) were at risk or severely delayed (i.e., 1 or more SD below the mean) for the composite language domain, 19.6\% (22/112) were at risk or severely delayed for the composite motor domain and $10.7 \%(12 / 112)$ were at risk or severely delayed for the composite cognitive domain.

Crude analyses indicated strong evidence that children born into households with an income up to $2 \times$ minimum wage have 5.69 times ( $95 \%$ CI 2.43 to 13.33 ) the odds of having microcephaly compared to those born into a household with income over $2 \times$ minimum wage (Table 2$)$. There was also a positive association between household participation in BF and the odds of microcephaly (OR, $95 \%$ CI: $2.55,1.08$ to 6.00 ). In addition, an increase in the level of maternal education, from primary to secondary school and to higher education, was strongly associated with a decrease in microcephaly odds $(p<0.001)$. The crude odds ratios for children with a mother with secondary school education and higher education compared with primary education were $0.37(0.14,0.99)$ and $0.12(0.04,0.38)$, respectively. Mothers who identified as Black Afro-Brazilian had the highest odds of having a child with microcephaly (OR, 95\% CI: 3.55, 1.29 to 9.80), compared to the group with children born to mothers who identified as White Brazilian and East Asian Brazilian. In addition, there was evidence for a linear association between household crowding index (HCI) groups and the odds of microcephaly (OR, 95\% CI: $1.79,1.23$ to 2.61 ) and no evidence for departures from linearity $(p=0.956)$. 
Table 1. Baseline distribution of selected cohort characteristics $(n=163)$.

\begin{tabular}{|c|c|c|c|}
\hline Variable & Category & Total, No. & $\begin{array}{c}\text { No. }(\operatorname{col} \%) / \\
\text { Median (IQR) }\end{array}$ \\
\hline \multicolumn{4}{|c|}{ Characteristics of children } \\
\hline \multirow{2}{*}{ Sex } & Female & 163 & $84(51.5 \%)$ \\
\hline & Male & & $79(48.5 \%)$ \\
\hline Gestational age (weeks) & & 163 & $38(38-40)$ \\
\hline Birthweight $(\mathrm{g})$ & & 163 & $3060(2675-3420)$ \\
\hline Age at last Bayley-III test (months) & & 112 & $19.6(12.8-36.0)$ \\
\hline \multicolumn{4}{|c|}{ Characteristics of mothers } \\
\hline Age at enrolment (years) & Median (IQR) & 126 & $30.8(23.6-34.7)$ \\
\hline \multirow{3}{*}{ Educational level } & Primary school, including partial & 147 & $22(15.0 \%)$ \\
\hline & Secondary school, including partial & & $77(52.4 \%)$ \\
\hline & Higher education, including partial & & $48(32.7 \%)$ \\
\hline \multirow{4}{*}{ Race/ethnicity } & White Brazilians & 145 & $53(36.6 \%)$ \\
\hline & Mixed-race Afro-Brazilians & & $66(45.5 \%)$ \\
\hline & Black Afro-Brazilians & & $23(15.9 \%)$ \\
\hline & East Asian Brazilians & & $3(2.1 \%)$ \\
\hline \multirow{3}{*}{ Parity } & $\leq 1$ & 151 & $81(53.6 \%)$ \\
\hline & 2 & & $50(33.1 \%)$ \\
\hline & $3+$ & & $20(13.3 \%)$ \\
\hline \multirow{2}{*}{ Previous miscarriage or abortion } & No & 143 & $117(81.8 \%)$ \\
\hline & Yes & & $26(19.2 \%)$ \\
\hline \multirow{3}{*}{ Trimester of pregnancy with rash } & First & 130 & $56(43.1 \%)$ \\
\hline & Second & & $49(37.7 \%)$ \\
\hline & Third & & $25(19.2 \%)$ \\
\hline \multirow{2}{*}{ Smoking during pregnancy } & No & 145 & $139(95.9 \%)$ \\
\hline & Yes & & $6(4.1 \%)$ \\
\hline \multirow{2}{*}{ Drug use during pregnancy } & No & 146 & $138(94.5 \%)$ \\
\hline & Yes & & $8(5.5 \%)$ \\
\hline \multirow{2}{*}{$\begin{array}{l}\text { Occupational exposure to toxic } \\
\text { products during pregnancy }\end{array}$} & No & 143 & $111(77.6 \%)$ \\
\hline & Yes & & $32(22.4 \%)$ \\
\hline \multicolumn{4}{|c|}{ Characteristics of household } \\
\hline \multirow{5}{*}{$\begin{array}{l}\text { Monthly income (relative to } 2019 \\
\text { minimum wage of BRL 998) }\end{array}$} & Class A: $>20 \times$ minimum wage & 132 & $2(1.5 \%)$ \\
\hline & Class B: $10-20 \times$ minimum wage & & $7(5.3 \%)$ \\
\hline & Class C: $4-10 \times$ minimum wage & & $18(13.6 \%)$ \\
\hline & Class D: $2-4 \times$ minimum wage & & $38(28.8 \%)$ \\
\hline & Class E: $<2 \times$ minimum wage & & $67(50.8 \%)$ \\
\hline \multirow{2}{*}{ Participation in Bolsa Família } & No & 138 & $111(80.4 \%)$ \\
\hline & Yes & & $27(19.6 \%)$ \\
\hline \multirow{4}{*}{ Household crowding index } & $<0.50$ & 136 & $38(27.9 \%)$ \\
\hline & $0.50-0.75$ & & $46(33.8 \%)$ \\
\hline & $0.75-1.00$ & & $33(24.3 \%)$ \\
\hline & $1.00+$ & & $19(14.0 \%)$ \\
\hline
\end{tabular}




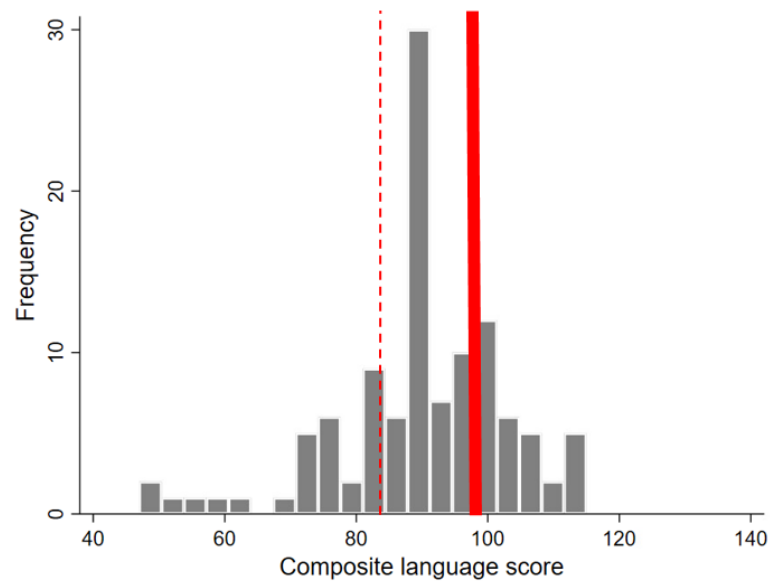

(a)

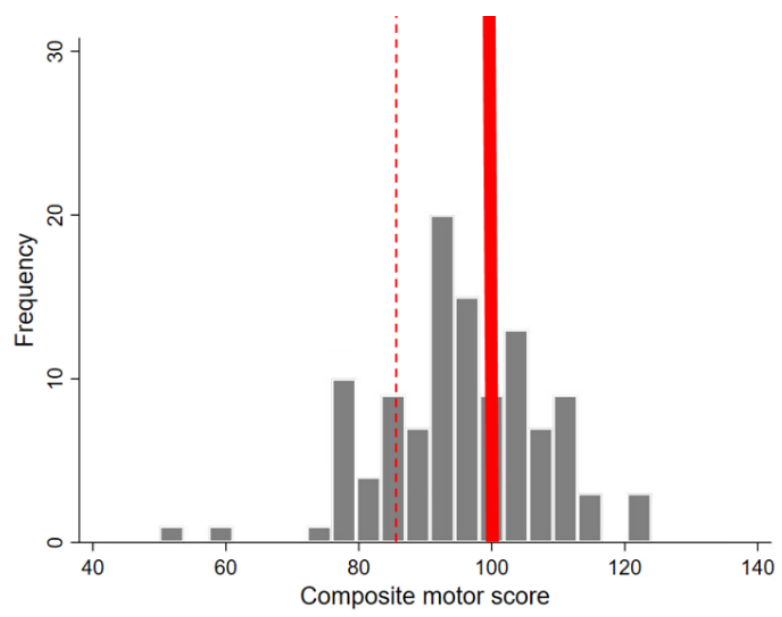

(b)

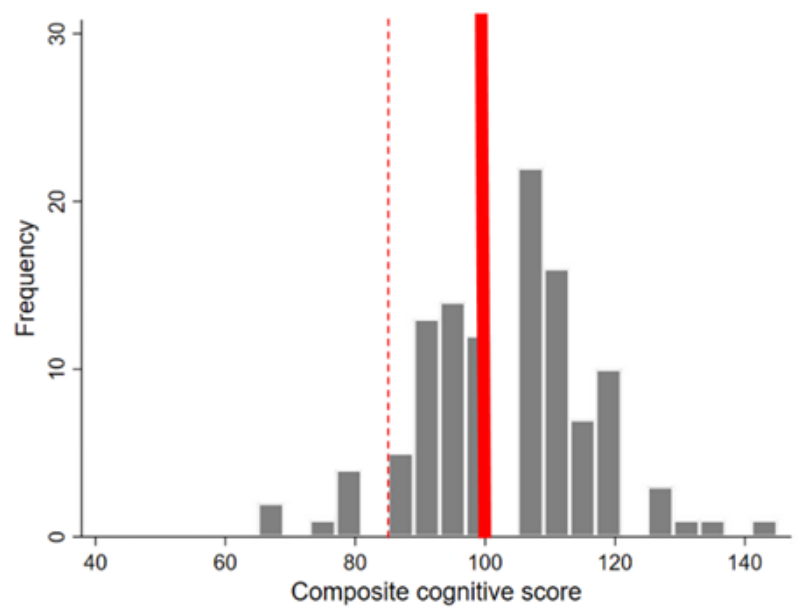

(c)

Figure 3. Histograms of composite language (a), motor (b) and cognitive (c) scores from Bayley-III assessments (thick red lines indicate the mean in a normative population (100) and dotted red lines indicate the threshold for developmental delay (at risk or severely delayed) at 1 or more SD below the mean (i.e., a score $\leq 85)$ ). 
Table 2. Baseline distribution of child, maternal and household characteristics with crude odds ratios of microcephaly in children exposed to ZIKV in utero $(n=163)$.

\begin{tabular}{|c|c|c|c|c|c|}
\hline Variable & Category & $\begin{array}{l}\text { Number of } \\
\text { Children } \\
\text { Exposed to } \\
\text { ZIKV In Utero }\end{array}$ & $\begin{array}{l}\text { No. (Row \%) of } \\
\text { Exposed } \\
\text { Children with } \\
\text { Microcephaly }\end{array}$ & $\begin{array}{l}\text { Crude Odds } \\
\text { Ratio }(95 \% \text { CI) }\end{array}$ & $p$ Value $* * *$ \\
\hline \multicolumn{6}{|c|}{ Characteristics of children } \\
\hline \multirow{2}{*}{ Sex } & Female & 84 & $27(32.1 \%)$ & 1 & 0.808 \\
\hline & Male & 79 & $24(30.4 \%)$ & $0.92(0.47,1.79)$ & \\
\hline \multicolumn{6}{|c|}{ Characteristics of mothers } \\
\hline \multirow{4}{*}{ Educational level } & $\begin{array}{l}\text { Primary school, } \\
\text { including partial }\end{array}$ & 22 & $13(59.1 \%)$ & 1 & $<0.001$ \\
\hline & $\begin{array}{l}\text { Secondary school, } \\
\text { including partial }\end{array}$ & 77 & $27(35.1 \%)$ & $0.37(0.14,0.99)$ & \\
\hline & $\begin{array}{l}\text { Higher education, } \\
\text { including partial }\end{array}$ & 48 & $7(14.6 \%)$ & $0.12(0.04,0.38)$ & \\
\hline & Missing & 16 & $4(25.0 \%)$ & & \\
\hline \multirow{4}{*}{ Race/ethnicity } & $\begin{array}{l}\text { White Brazilian and } \\
\text { East Asian Brazilian }\end{array}$ & 56 & $15(26.8 \%)$ & 1 & 0.038 \\
\hline & $\begin{array}{c}\text { Mixed-race } \\
\text { Afro-Brazilian }\end{array}$ & 66 & $19(28.8 \%)$ & $1.10(0.50,2.45)$ & \\
\hline & Black Afro-Brazilian & 23 & $13(56.5 \%)$ & $3.55(1.29,9.80)$ & \\
\hline & Missing & 18 & $4(22.2 \%)$ & & \\
\hline \multirow{4}{*}{ Parity } & $\leq 1$ & 81 & $24(29.6 \%)$ & 1 & 0.887 \\
\hline & 2 & 50 & $16(32.0 \%)$ & $1.12(0.52,2.39)$ & \\
\hline & $3+$ & 20 & $7(35.0 \%)$ & $1.28(0.45,3.60)$ & \\
\hline & Missing & 12 & $4(33.3 \%)$ & & \\
\hline \multirow{2}{*}{$\begin{array}{c}\text { Previous } \\
\text { miscarriage or abortion }\end{array}$} & No & 117 & $37(31.6 \%)$ & 1 & 0.506 \\
\hline & Yes & 26 & $10(38.5 \%)$ & $1.35(0.56,3.26)$ & \\
\hline \multirow{4}{*}{$\begin{array}{l}\text { Trimester of pregnancy } \\
\text { with rash }\end{array}$} & First & 56 & $31(55.4 \%)$ & 1 & $<0.001$ \\
\hline & Second & 49 & $3(6.1 \%)$ & $0.05(0.01,0.19)$ & \\
\hline & Third & 25 & $2(8.0 \%)$ & $0.07(0.02,0.33)$ & \\
\hline & Missing & 33 & $15(45.5 \%)$ & & \\
\hline \multirow{3}{*}{$\begin{array}{l}\text { Smoking during } \\
\text { pregnancy }\end{array}$} & No & 139 & $44(31.7 \%)$ & 1 & 0.363 \\
\hline & Yes & 6 & $3(50.0 \%)$ & $\begin{array}{l}2.16(0.42 \\
11.13)\end{array}$ & \\
\hline & Missing & 18 & $4(22.2 \%)$ & & \\
\hline \multirow{3}{*}{$\begin{array}{l}\text { Drug use during } \\
\text { pregnancy }\end{array}$} & No & 138 & $44(31.9 \%)$ & 1 & 0.744 \\
\hline & Yes & 8 & $3(37.5 \%)$ & $1.28(0.29,5.61)$ & \\
\hline & Missing & 17 & $4(23.5 \%)$ & & \\
\hline \multirow{3}{*}{$\begin{array}{l}\text { Occupational exposure } \\
\text { to toxic products } \\
\text { during pregnancy }\end{array}$} & No & 111 & $37(33.3 \%)$ & 1 & 0.824 \\
\hline & Yes & 32 & $10(31.3 \%)$ & $0.90(0.39,2.12)$ & \\
\hline & Missing & 20 & $4(20.0 \%)$ & & \\
\hline \multicolumn{6}{|c|}{ Characteristics of household } \\
\hline \multirow{3}{*}{$\begin{array}{l}\text { Income per month } \\
\text { (relative to minimum } \\
\text { wage) }\end{array}$} & $\begin{array}{l}\text { Classes A, B, C and D: } \\
>2 \times \text { min wage }\end{array}$ & 65 & $9(13.8 \%)$ & 1 & $<0.001$ \\
\hline & Class E: $<2 \times$ min wage & 67 & $32(47.8 \%)$ & $\begin{array}{c}5.69(2.43 \\
13.33)\end{array}$ & \\
\hline & Missing & 31 & $10(32.3 \%)$ & & \\
\hline \multirow{3}{*}{$\begin{array}{l}\text { Participation in Bolsa } \\
\text { Família }\end{array}$} & No & 111 & $33(29.7 \%)$ & 1 & 0.033 \\
\hline & Yes & 27 & $14(51.9 \%)$ & $2.55(1.08,6.00)$ & \\
\hline & Missing & 25 & $4(16.0 \%)$ & & \\
\hline \multirow{5}{*}{$\begin{array}{l}\text { Household crowding } \\
\text { index }\end{array}$} & $<0.5$ & 38 & $7(18.4 \%)$ & 1 & 0.081 \\
\hline & $0.5-0.75$ & 46 & $13(28.3 \%)$ & $1.74(0.62,4.94)$ & \\
\hline & $0.75-1.0$ & 33 & $13(39.4 \%)$ & $2.88(0.98,8.45)$ & \\
\hline & $1.0+$ & 19 & $11(57.9 \%)$ & $\begin{array}{c}6.09(1.79 \\
20.74)\end{array}$ & \\
\hline & Missing & 27 & $7(25.9 \%)$ & & \\
\hline
\end{tabular}

* $p$ values do not include missing data categories. ${ }^{* *}$ The likelihood ratio test was used to assess the strength of the evidence of the association between exposure variables and outcomes.

Upon adjustment for child's sex and household income, there was no statistical evidence of an association between race/ethnicity and microcephaly. The multivariate analysis indicated that having a household income of up to $2 \times$ minimum wage showed strong statistical evidence of an association 
with microcephaly (OR, 95\% CI: 3.85, 1.43 to 10.37). Accounting for child's sex and birthweight, lower maternal education was associated with an increase in microcephaly $(p<0.001)$. The adjusted odds for children with a mother with secondary school education and higher education compared with primary education were 0.33 (95\% CI: 0.11 to 0.98$)$ and 0.10 (95\% CI: 0.01 to 0.36), respectively. After adjusting for child's sex, maternal education and maternal parity, a linear trend was observed across the four household crowding index groups, such that each increase in household crowding index group (i.e., from least to most crowded) was associated with an $83 \%$ increase in the odds of microcephaly (OR, 95\% CI: 1.83, 1.16 to 2.91) (Table 3). Consistent patterns of association were observed in sensitivity analyses including children without lab confirmation of prenatal ZIKV exposure (Table A2).

Table 3. Multivariate associations of socioeconomic indicators with microcephaly cases.

\begin{tabular}{|c|c|c|c|}
\hline Variable & Category & $\begin{array}{l}\text { Adjusted Odds } \\
\text { Ratio }(95 \% \mathrm{CI})\end{array}$ & $p$ Value * \\
\hline $\begin{array}{l}\text { Maternal educational level }{ }^{\mathrm{a}} \\
\qquad n=147\end{array}$ & $\begin{array}{l}\text { Primary school, including partial } \\
\text { Secondary school, including partial } \\
\text { Higher education, including partial }\end{array}$ & $\begin{array}{c}1 \\
0.33(0.11,0.98) \\
0.10(0.03,0.36)\end{array}$ & $<0.001$ \\
\hline $\begin{array}{l}\text { Maternal race/ethnicity } b \\
\qquad n=129\end{array}$ & $\begin{array}{c}\text { White Brazilian and East Asian Brazilian } \\
\text { Mixed-race Afro-Brazilian } \\
\text { Black Afro-Brazilian }\end{array}$ & $\begin{array}{c}1 \\
0.89(0.35,2.27) \\
1.79(0.55,5.86)\end{array}$ & 0.439 \\
\hline $\begin{array}{l}\text { Household monthly income }{ }^{\mathrm{c}} \\
\qquad n=122\end{array}$ & $\begin{array}{c}\text { Classes A, B, C and D: }>2 \times \text { min wage } \\
\text { Class } E:<2 \times \text { min wage }\end{array}$ & $\begin{array}{c}1 \\
3.85(1.43,10.37)\end{array}$ & 0.006 \\
\hline $\begin{array}{l}\text { Household participation in Bolsa } \\
\text { Família } \mathrm{d} \\
n=135\end{array}$ & $\begin{array}{l}\text { No } \\
\text { Yes }\end{array}$ & $\begin{array}{c}1 \\
1.74(0.69,4.37)\end{array}$ & 0.239 \\
\hline $\begin{array}{l}\text { Household crowding index } \mathrm{e} \\
\qquad n=129\end{array}$ & $\begin{array}{l}\text { Household crowding index groups }(<0.5, \\
0.5-0.75,0.75-1.0,1.0+)\end{array}$ & $1.83(1.16,2.91)$ & 0.008 \\
\hline \multicolumn{4}{|c|}{$\begin{array}{l}\text { a adjusted for child's sex, birthweight; }{ }^{b} \text { adjusted for child's sex, household income; }{ }^{c} \text { adjusted for child's sex, } \\
\text { household crowding index, maternal education; }{ }^{d} \text { adjusted for child's sex, maternal education, previous miscarriage } \\
\text { or abortion; }{ }^{\text {e }} \text { adjusted for child's sex, maternal education, maternal parity; }{ }^{*} \text { The likelihood ratio test was used to } \\
\text { assess the strength of the evidence of the association of exposure variables and outcomes. }\end{array}$} \\
\hline
\end{tabular}

After adjusting for child sex, gestational age, maternal education, maternal race/ethnicity, household crowding index, maternal parity, previous miscarriage or abortion and birthweight, there was evidence of an association between household participation in Bolsa Família and a lower composite language score of -10.78 (95\% CI: -19.87 to -1.69$)$, a lower composite motor score of -10.45 (95\% CI: -19.22 to -1.69 ) and a lower composite cognitive score of -17.20 (95\% CI: -26.13 to -8.28 ) (Table 4). Bayley-III assessment scores did not appear to vary by other socioeconomic indicators in this study sample. Unadjusted estimates are presented in the appendices (Table A3). 
Table 4. Adjusted estimated differences in Bayley-III assessment scores according to risk factors, in the normocephalic study sample ( $\mathrm{n}=112$ ).

\begin{tabular}{|c|c|c|c|c|c|c|c|}
\hline & & Composite Language & & Composite Motor & & Composite Cognitive & \\
\hline Variables & Categories & $\begin{array}{c}\text { Adjusted Estimated } \\
\text { Difference in Composite } \\
\text { Scores }(95 \% \text { CI })\end{array}$ & $p$ Value * & $\begin{array}{c}\text { Adjusted Estimated } \\
\text { Difference in Composite } \\
\text { Scores }(95 \% \text { CI })\end{array}$ & $p$ Value * & $\begin{array}{c}\text { Adjusted Estimated } \\
\text { Difference in Composite } \\
\text { Scores }(95 \% \text { CI })\end{array}$ & $p$ Value * \\
\hline \multirow{3}{*}{$\begin{array}{l}\text { Maternal educational } \\
\text { level }^{\text {a }} \\
n=83\end{array}$} & Primary school, including partial & (Reference) & \multirow[t]{3}{*}{0.821} & (Reference) & \multirow[t]{3}{*}{0.975} & (Reference) & \multirow[t]{3}{*}{0.200} \\
\hline & Secondary school, including partial & $3.31(-7.96,14.57)$ & & $-0.21(-10.69,10.26)$ & & $-4.19(-15.09,6.71)$ & \\
\hline & Higher education, including partial & $3.00(-8.61,14.57)$ & & $0.51(-10.27,11.29)$ & & $1.80(-9.41,13.01)$ & \\
\hline \multirow{2}{*}{$\begin{array}{l}\text { Maternal } \\
\text { race/ethnicity }{ }^{\mathrm{b}} \\
n=76\end{array}$} & $\begin{array}{l}\text { White Brazilians and East Asian } \\
\text { Brazilians }\end{array}$ & (Reference) & \multirow[t]{2}{*}{0.945} & (Reference) & \multirow[t]{2}{*}{0.253} & (Reference) & \multirow[t]{2}{*}{0.262} \\
\hline & Mixed-race Afro-Brazilians & $0.88(-6.29,8.05)$ & & $2.86(-3.97,9.69)$ & & $4.56(-2.33,11.46)$ & \\
\hline \multirow{2}{*}{$\begin{array}{l}\text { Household monthly } \\
\text { income }^{\mathrm{c}} \\
n=78\end{array}$} & $\begin{array}{l}\text { Classes A, B, C and D: } \\
>2 \times \text { min wage }\end{array}$ & (Reference) & \multirow[t]{2}{*}{0.411} & (Reference) & \multirow[t]{2}{*}{0.594} & (Reference) & \multirow[t]{2}{*}{0.905} \\
\hline & Class E: $<2 \times$ min wage & $2.77(-4.58,10.13)$ & & $1.72(-5.35,8.80)$ & & $0.41(-7.12,7.95)$ & \\
\hline $\begin{array}{l}\text { Household } \\
\text { participation in Bolsa } \\
\text { Família }{ }^{d} \\
n=80\end{array}$ & $\begin{array}{l}\text { No } \\
\text { Yes }\end{array}$ & $\begin{array}{c}\text { (Reference) } \\
-10.78(-19.87,-1.69)\end{array}$ & 0.011 & $\begin{array}{c}\text { (Reference) } \\
-10.45(-19.22,-1.69)\end{array}$ & 0.011 & $\begin{array}{c}\text { (Reference) } \\
-17.20(-26.13,-8.28)\end{array}$ & $<0.001$ \\
\hline $\begin{array}{l}\text { Household crowding } \\
\text { index } \mathrm{e} \\
n=76\end{array}$ & $\begin{array}{l}\text { Linear trend across four household } \\
\text { crowding index groups }(<0.5, \\
0.5-0.75,0.75-1.0,1.0+)\end{array}$ & $-1.45(-5.11,2.20)$ & 0.380 & $1.44(-2.05,4.92)$ & 0.363 & $2.79(-0.72,6.30)$ & 0.082 \\
\hline
\end{tabular}

${ }^{a}$ adjusted for child sex, gestational age, maternal race/ethnicity, household income, household participation in Bolsa Família, household crowding index. ${ }^{\mathrm{b}}$ adjusted for child sex, gestational age, maternal education, household income, household participation in Bolsa Família, household crowding index, maternal parity, previous miscarriage or abortion, birthweight. ${ }^{c}$ adjusted for child sex, gestational age, maternal education, maternal race/ethnicity, household crowding index, maternal parity, previous miscarriage or abortion, birthweight. $\mathrm{d}$ adjusted for child sex, gestational age, maternal education, maternal race/ethnicity, household crowding index, maternal parity, previous miscarriage or abortion, birthweight. $\mathrm{e}$ adjusted for child sex, gestational age, maternal education, maternal race/ethnicity, household income, household participation in Bolsa Família, maternal parity, previous miscarriage or abortion, birthweight. ${ }^{*}$ The likelihood ratio test was used to assess the strength of the evidence of the association between exposure variables and outcomes. 


\section{Discussion}

In a cohort of 163 infants with prenatal ZIKV exposure in Rio de Janeiro, Brazil, a consistent relationship between adverse neurodevelopmental outcomes and unfavourable socioeconomic indicators was observed. Specifically, these findings provide evidence of an association of microcephaly with lower household income, higher household crowding and lower maternal education. In line with these results, economically deprived children with prenatal ZIKV exposure also appeared to be at greater risk of delayed neurodevelopment during the early life course. Adjusted models provided statistical evidence of lower composite language, motor and cognitive scores in children whose families participated in the in the Bolsa Família social protection programme. Taken together, these findings reinforce the idea that early disadvantage can drive differential health and developmental outcomes [7].

Results from this study are consistent with previous research undertaken at the population level. An ecological analysis completed between 2015 and 2016 in Recife, Brazil, described a strong association between microcephaly from ZIKV infection and poor living conditions, such that only $2.0 \%$ of the microcephaly cases resided in the wealthiest districts [5]. Another ecological study conducted using socioeconomic and health status data from the five regions in Brazil reported a strong correlation between the distribution of ZIKV-related microcephaly cases and poverty as measured in an index $(p<0.0001)$ [20], suggesting the potential for co-acting socioeconomic factors in the microcephaly epidemic [21].

Adverse environmental conditions often cluster together in socially patterned ways [22]. People with low SEP are likely to live in adverse social circumstances, be of low birthweight and be exposed to poor diets [23]. A 1990-1991 cross-sectional study, investigating Aboriginal children under 2 years in Australia provided evidence that wasting was strongly associated with microcephaly on admission to a tertiary referral centre for diarrhoea, independent of intrauterine growth restriction and low birthweight. Low household income may drive food insecurity and thus malnutrition. Malnutrition, in important periods of intra- and extra-uterine development, could cause irreversible damage to intellectual potential and behaviour [24].

Often, where household crowding exists, neighbourhood overcrowding persists. The built environment in poor urban areas may also provide abundant habitats for mosquito proliferation through insufficient infrastructure [25]. In addition, housing can be seen as a key component of wealth as it often accounts for a large proportion of outgoings from income [26].

Education is a frequently used indicator of SEP with origins in the status domain of Weberian theory [26]. The variable of maternal education reflects mothers' early life SEPs and captures their knowledge-related assets over the life course [26]. Inferences have been made in previous studies about how the underlying social environment, including low maternal education, may play a role in the development of neonatal microcephaly [27,28]. Two 2010 birth cohort studies conducted in Brazil concluded that low maternal schooling was consistently associated with microcephaly, suggesting that prior to the ZIKV epidemic, there may have been a silent endemic of microcephaly caused by other risk factors associated with poverty [28]. Crude analyses revealed a strong association between women who identified as Black Afro-Brazilian and having a child with microcephaly. After controlling for confounders, including household income, there was no statistical evidence of this association. This points to structural racism as a potential driver of neurodevelopmental disparities. Structural racism is defined by social epidemiologist, Nancy Krieger (2014) as “ ... ways in which societies foster [racial] discrimination ... that in turn reinforce discriminatory beliefs, values, and distribution of resources" [29]. Many residents in Rio de Janeiro live in racialised and economically segregated areas of the city [30], which could be associated with health outcomes, including birth outcomes, as previously observed in the US context [31].

Furthermore, the findings from this study may be related to a lack of access to abortion services. Since abortion in Brazil is considered a crime against human life, except under exceptional circumstances, quantifying self-induced or unregulated abortion is extremely challenging [32]. Illegal options are 
available at a cost. Thus, one potential pathway for the outcomes observed is that those with lower household income may not have the means to pay for an abortion.

This investigation revealed lower composite language, motor and cognitive scores in children whose families were recipients of Bolsa Família. Whilst participation in Bolsa Família can be viewed as a proxy indicator for poverty as it is dependent on having a per capita monthly income $\leq$ BRL 140 (US \$35.00), it also indicates receipt of financial and social support. Those eligible for the programme must ensure compliance with selected activities, including schooling and vaccination for children and pre- and post-natal care for women [33]. This poverty-alleviating programme has the potential to improve poor health and development opportunities, as has been shown for diseases like leprosy [33,34]. An important concern in the current investigation may therefore be residual confounding. Thus, this warrants further investigation. Furthermore, eligibility assessments for this programme are made every two years; however, social circumstances may change over time. This highlights the challenges inherent in investigating social determinants of health without utilising a life course approach [22].

This investigation is a unique and important analysis. Whilst social determinants of ZIKV and CZS have been investigated primarily through ecological studies, this is the first study to describe the association of SEP at the individual level with microcephaly and delayed neurodevelopment following in utero exposure to ZIKV. Nevertheless, this study had important limitations. First, Rio de Janeiro presents a unique context of inequality, poverty, urban segregation and deficient infrastructure [35]. The results obtained from this study are therefore specific to this urban setting and thus may not be generalisable to rural communities in Brazil or indeed other urban environments outside of Brazil. Second, although a strength of this study is that it used stringent inclusion criteria and eligible infants were enrolled only if they had nucleic acid and/or serologic evidence of prenatal ZIKV exposure, it was not possible to confirm congenital ZIKV infection in all of the participating children. Third, the enrolment procedure may have introduced systematic error through selection bias. This dataset was biased towards children born with CZS, as women who were asymptomatic or who did not appear to have foetal abnormalities during pregnancy were not enrolled in the cohort. Whilst frequencies of outcomes are likely to be higher than the general population, the same selective forces within the study population that resulted in the outcomes of interest are expected to be similar across exposure groups. This is therefore unlikely to have distorted effect estimates. In addition, whilst the Unified Health System (Sistema Único de Saúde) has helped Brazil to progress towards universal health coverage, structural weaknesses as well as economic and political crises have resulted in disparities in access to effective care [36]. The poorest are less likely to frequent healthcare facilities and the wealthiest often utilise high-cost private clinics. Those of lower SEP not only experience access inequity but poorer knowledge of the full implications of ZIKV and reduced health-seeking behaviour [37]. Under-representation of the lowest and highest SEP categories may have resulted in different measurements of outcomes within these groups, though comparisons between them are still accurate. Fourth, if children did not appear to have microcephaly at birth, parents may have been reluctant to attend the hospital for further evaluations, as CZS is a highly stigmatising diagnosis [38]. This suggests likely attrition bias within the normocephalic group. If the participants with lower SEP who were lost to follow-up are at greater risk of neurodevelopmental delays, then the study will have underestimated the effect of low SEP. Furthermore, hospital visits are time-consuming and economic losses may occur following time off work. Fifth, self-reporting of the exposure variables may have resulted in non-differential social desirability bias, particularly with respect to reporting income, drug-taking and smoking. Since this would increase the similarity between the exposed and non-exposed, any true association between low SEP and the outcome measures would be attenuated. This is not likely to have been exacerbated by requirements in place to be a beneficiary of Bolsa Família, since decisions are based on data captured within the national administrative database, Cadastro Único para Programas Sociais [33]. Finally, sudden and unexpected disease outbreaks, such as the recent ZIKV epidemic, have erupted in settings with notable resource constraints $[39,40]$. Strategic decisions 
are thus required to optimise available resources but may lead to missing data, limited sample sizes and losses to follow-up [39]. Conducting analyses on clinical studies in these climates, as this study does, whilst challenging, provides important insight into novel and unknown disease patterns and global health problems.

\section{Conclusions}

This report provides new evidence of the link between social determinants and the risk of microcephaly and delayed childhood neurodevelopment following in utero exposure to ZIKV. These findings suggest that targeting interventions, such as culturally appropriate and economically viable vector control measures, to socioeconomically marginalised groups may aid in reducing the disease burden of ZIKV in the case of a future epidemic. More broadly, this research also reflects the need in ZIKV research to expand the focus from a strictly biomedical paradigm of health and developmental outcomes, in which diagnosis and treatment focus on an individual's biology, to an integrated approach that addresses social factors [41]. Further research will be valuable for delineating the mechanisms by which low SEP may exert corrosive effects following prenatal exposure to ZIKV.

Author Contributions: Conceptualisation, G.M.P., E.B.B., M.E.M.; Methodology, G.M.P., E.B.B.; Software, G.M.P.; Validation, E.B.B.; Formal analysis, G.M.P., Investigation, G.M.P.; Resources, M.E.M., Z.V., P.B.; Data Curation, Z.V.; Writing-Original Draft Preparation, G.M.P.; Writing—Review and Editing, G.M.P., S.C.F., N.S.C., Z.V., P.B., K.N.-S., E.B.B., M.E.M.; Visualisation, G.M.P., E.B.B., M.E.M.; Supervision, E.B.B., M.E.M.; Project Administration, G.M.P. All authors have read and agreed to the published version of the manuscript.

Funding: This research was funded by the European Union's Horizon 2020 research and innovation programme, ZikaPLAN, under Grant Agreement No. 734584; Wellcome Trust \& the UK's Department for International Development (205377/Z/16/Z); and Fiocruz PIP/IFF program, CNPq 441098/2016-9 and 305090/2016-0; Faperj E_18/2015TXB.

Acknowledgments: We would like to thank the field team at IFF/Fiocruz for their guidance and support in consolidating and making available the data for this study and, in particular, Yasmin Villarosa, who regularly amended the database where discrepancies appeared.

Conflicts of Interest: The authors declare no conflict of interest. The funders had no role in the design of the study; in the collection, analyses, or interpretation of data; in the writing of the manuscript, or in the decision to publish the results. 


\section{Appendix A}

Table A1. Missingness patterns with percentages of missing data for each variable and baseline information stratified into two groups: cases with complete data and cases with missing data $(n=163)$.

\begin{tabular}{|c|c|c|c|c|c|c|}
\hline Variable & Category & Total, No. & $\begin{array}{l}\% \text { Non-Missing } \\
\text { Data }\end{array}$ & $\begin{array}{l}\text { Cases with Complete } \\
\text { Data No. }(\%) n=83\end{array}$ & $\begin{array}{l}\text { Cases with Missing } \\
\text { Data No. }(\%)\end{array}$ & $p$ Value \\
\hline \multicolumn{7}{|c|}{ Characteristics of children } \\
\hline \multirow{2}{*}{ Child sex } & Female & 163 & $100 \%$ & 41 & 43 & 0.578 \\
\hline & Male & & & 42 & 37 & \\
\hline \multicolumn{7}{|c|}{ Characteristics of mothers } \\
\hline \multirow{3}{*}{ Maternal educational level } & Primary school, including partial & 147 & $90 \%$ & 16 & 6 & 0.119 \\
\hline & Secondary school, including partial & & & 38 & 39 & \\
\hline & Higher education, including partial & & & 29 & 10 & \\
\hline \multirow{3}{*}{ Maternal race/ethnicity } & $\begin{array}{l}\text { White Brazilian and East Asian } \\
\text { Brazilian }\end{array}$ & 145 & $89 \%$ & 34 & 22 & 0.645 \\
\hline & Mixed-race Afro-Brazilian & & & 35 & 31 & \\
\hline & Black Afro-Brazilian & & & 14 & 9 & \\
\hline \multirow{3}{*}{ Maternal parity } & $\leq 1$ & 151 & $93 \%$ & 41 & 40 & 0.291 \\
\hline & 2 & & & 32 & 18 & \\
\hline & $3+$ & & & 10 & 10 & \\
\hline \multirow{2}{*}{ Previous miscarriage or abortion } & No & 143 & $88 \%$ & 69 & 48 & 0.632 \\
\hline & Yes & & & 14 & 12 & \\
\hline \multirow{3}{*}{ Trimester of pregnancy with rash } & First & 130 & $80 \%$ & 39 & 17 & 0.443 \\
\hline & Second & & & 30 & 19 & \\
\hline & Third & & & 14 & 11 & \\
\hline \multirow{2}{*}{ Did the mother smoke during pregnancy } & No & 145 & $89 \%$ & 79 & 60 & 0.634 \\
\hline & Yes & & & 4 & 2 & \\
\hline \multirow{2}{*}{ Did the mother use drugs during pregnancy } & No & 146 & $90 \%$ & 80 & 58 & 0.256 \\
\hline & Yes & & & 3 & 5 & \\
\hline \multirow{2}{*}{$\begin{array}{l}\text { Occupational exposure to toxic products } \\
\text { during pregnancy }\end{array}$} & No & 143 & $88 \%$ & 65 & 46 & 0.816 \\
\hline & Yes & & & 18 & 14 & \\
\hline
\end{tabular}


Table A1. Cont.

\begin{tabular}{|c|c|c|c|c|c|c|}
\hline Variable & Category & Total, No. & $\begin{array}{c}\% \text { Non-Missing } \\
\text { Data }\end{array}$ & $\begin{array}{c}\text { Cases with Complete } \\
\text { Data No. }(\%) n=83\end{array}$ & $\begin{array}{c}\text { Cases with Missing } \\
\text { Data No. (\%) }\end{array}$ & $p$ Value \\
\hline \multicolumn{7}{|c|}{ Characteristics of household } \\
\hline \multirow{5}{*}{$\begin{array}{l}\text { Household monthly income (relative to } \\
\text { minimum wage of BRL998) }\end{array}$} & Class A: $>20 \times$ minimum wage & 132 & $81 \%$ & 38 & 29 & 0.684 \\
\hline & Class B: $10-20 \times$ minimum wage & & & 5 & 2 & \\
\hline & Class C: $4-10 \times$ minimum wage & & & 12 & 6 & \\
\hline & Class D: $2-4 \times$ minimum wage & & & 26 & 12 & \\
\hline & Class $\mathrm{E}:<2 \times$ minimum wage & & & 38 & 29 & \\
\hline \multirow{2}{*}{$\begin{array}{l}\text { Household participation in Bolsa Família } \\
\text { (government cash transfer scheme) }\end{array}$} & No & 138 & $85 \%$ & 67 & 61 & 0.513 \\
\hline & Yes & & & 16 & 11 & \\
\hline \multirow{4}{*}{$\begin{array}{l}\text { Household crowding index (individuals in } \\
\text { the house / rooms in the house) }\end{array}$} & $<0.5$ & 136 & $83 \%$ & 23 & 15 & 0.584 \\
\hline & $0.5-0.75$ & & & 25 & 21 & \\
\hline & $0.75-1.0$ & & & 23 & 10 & \\
\hline & $1.0+$ & & & 12 & 7 & \\
\hline
\end{tabular}

\section{Appendix B}

Table A2. Multivariate associations of socioeconomic indicators with microcephaly cases in children with and without qRT-PCR or IgM confirmation with suspected prenatal ZIKV exposure $(n=286)$.

\begin{tabular}{|c|c|c|c|}
\hline Variable & Category & Adjusted Odds Ratio (95\% CI) & $p$ Value * \\
\hline $\begin{array}{l}\text { Maternal educational level }{ }^{\text {a }} \\
n=240\end{array}$ & $\begin{array}{l}\text { Primary school, including partial } \\
\text { Secondary school, including partial } \\
\text { Higher education, including partial }\end{array}$ & $\begin{array}{c}1 \\
0.71(0.33,1.54) \\
0.22(0.09,0.55)\end{array}$ & $<0.001$ \\
\hline $\begin{array}{l}\text { Maternal race/ethnicity }{ }^{\mathrm{b}} \\
n=212\end{array}$ & $\begin{array}{l}\text { White Brazilians and East Asian Brazilians } \\
\text { Mixed-race Afro-Brazilians } \\
\text { Black Afro-Brazilians }\end{array}$ & $\begin{array}{c}1 \\
0.83(0.34,1.99) \\
0.67(0.34,1.35)\end{array}$ & 0.526 \\
\hline $\begin{array}{l}\text { Household monthly income (relative to minimum wage) }{ }^{\mathrm{c}} \\
n=204\end{array}$ & $\begin{array}{l}\text { Classes A, B, C and D: }>2 \times \text { min wage } \\
\text { Class E: }<2 \times \text { min wage }\end{array}$ & $\begin{array}{c}1 \\
2.71(1.36,5.43)\end{array}$ & 0.004 \\
\hline $\begin{array}{l}\text { Household participation in Bolsa Família (government cash transfer) scheme }{ }^{\mathrm{d}} \\
n=224\end{array}$ & $\begin{array}{l}\text { No } \\
\text { Yes }\end{array}$ & $\begin{array}{c}1 \\
1.35(0.70,2.62)\end{array}$ & 0.371 \\
\hline $\begin{array}{l}\text { Household crowding index (individuals in the house/rooms in the house) }{ }^{\mathrm{e}} \\
n=207\end{array}$ & $\begin{array}{l}\text { Linear trend across four household crowding } \\
\text { index groups }(<0.5,0.5-0.75,0.75-1.0,1.0+)\end{array}$ & $1.48(1.06,2.09)$ & 0.021 \\
\hline
\end{tabular}

a adjusted for child's sex and birthweight. ${ }^{\mathrm{b}}$ adjusted for child's sex and household income. ${ }^{\mathrm{c}}$ adjusted for child's sex, household crowding index and maternal education. ${ }^{\mathrm{d}}$ adjusted for child's sex, maternal education and previous miscarriage or abortion. ${ }^{e}$ adjusted for child's sex, maternal education and maternal parity * The likelihood ratio test was used to assess the strength of the evidence of an association between exposure variables and outcomes. 


\section{Appendix C}

Table A3. Unadjusted estimated differences in Bayley-III assessment scores according to risk factors, in the normocephalic study sample $(n=112)$.

\begin{tabular}{|c|c|c|c|c|c|c|c|c|}
\hline Variable & Category & $\begin{array}{l}\text { No. (Col \%) of } \\
\text { Children } \\
\text { Taking } \\
\text { Bayley-III Tests }\end{array}$ & $\begin{array}{c}\text { Unadjusted } \\
\text { Estimated Difference } \\
\text { in Language Scores } \\
(95 \% \mathrm{CI})\end{array}$ & $p$ Value $* * *$ & $\begin{array}{c}\text { Unadjusted } \\
\text { Estimated Difference } \\
\text { in Motor Scores }(95 \% \\
\text { CI) }\end{array}$ & $p$ Value $* * *$ & $\begin{array}{c}\text { Unadjusted } \\
\text { Estimated Difference } \\
\text { in Cognitive Scores } \\
(95 \% \text { CI })\end{array}$ & $p$ Value $* * *$ \\
\hline \multicolumn{9}{|c|}{ Characteristics of children } \\
\hline Sex & $\begin{array}{l}\text { Female } \\
\text { Male }\end{array}$ & $\begin{array}{l}57(50.9 \%) \\
55(49.1 \%)\end{array}$ & $\begin{array}{c}\text { (Reference) } \\
-1.97(-6.90,2.96)\end{array}$ & 0.429 & $\begin{array}{c}\text { (Reference) } \\
-0.19(-4.84,4.47)\end{array}$ & 0.937 & $\begin{array}{c}\text { (Reference) } \\
0.81(-4.28,5.90)\end{array}$ & 0.752 \\
\hline \multicolumn{9}{|c|}{ Characteristics of mother } \\
\hline \multirow{4}{*}{ Educational level } & $\begin{array}{l}\text { Primary school, } \\
\text { including partial }\end{array}$ & $9(8.0)$ & (Reference) & 0.459 & (Reference) & 0.94 & (Reference) & 0.139 \\
\hline & $\begin{array}{l}\text { Secondary school, } \\
\text { including partial }\end{array}$ & $50(44.6 \%)$ & $2.34(-7.00,11.69)$ & & $-0.87(-9.84,8.10)$ & & $-3.63(-12.92,5.65)$ & \\
\hline & $\begin{array}{l}\text { Higher education, } \\
\text { including partial }\end{array}$ & $41(36.6 \%)$ & $5.03(-4.47,14.53)$ & & $0.01(-9.11,9.13)$ & & $1.79(-7.65,11.23)$ & \\
\hline & Missing & $12(10.7 \%)$ & & & & & & \\
\hline \multirow{3}{*}{ Race/ethnicity } & $\begin{array}{l}\text { White Brazilians and } \\
\text { East Asian Brazilians }\end{array}$ & $41(36.6 \%)$ & (Reference) & 0.55 & (Reference) & 0.369 & (Reference) & 0.947 \\
\hline & $\begin{array}{l}\text { Mixed-race } \\
\text { Afro-Brazilians }\end{array}$ & $47(42.0 \%)$ & $-2.78(-8.32,2.77)$ & & $3.67(-1.62,8.96)$ & & $0.74(-4.90,6.38)$ & \\
\hline & $\begin{array}{l}\text { Black Afro-Brazilians } \\
\text { Missing }\end{array}$ & $\begin{array}{c}10(8.9 \%) \\
14(12.5 \%)\end{array}$ & $-3.51(-12.67,5.64)$ & & $3.42(-5.31,12.15)$ & & $1.29(-8 .-1,10.60)$ & \\
\hline \multirow{4}{*}{ Parity } & $\leq 1$ & $57(50.9 \%)$ & (Reference) & 0.211 & (Reference) & 0.007 & (Reference) & 0.566 \\
\hline & 2 & $34(30.4 \%)$ & $0.66(-4.97,6.30)$ & & $-7.32(-12.49,-2.16)$ & & $0.93(-4.92,6.77)$ & \\
\hline & $3+$ & $13(11.6 \%)$ & $7.10(-0.89,15.10)$ & & $3.04(-4.28,10.37)$ & & $4.47(-3.82,12.76)$ & \\
\hline & Missing & $8(7.1 \%)$ & & & & & & \\
\hline \multirow{3}{*}{$\begin{array}{l}\text { Previous miscarriage or } \\
\text { abortion }\end{array}$} & No & $80(71.4 \%)$ & (Reference) & 0.62 & (Reference) & 0.552 & [Reference) & 0.932 \\
\hline & Yes & $16(14.3 \%)$ & $1.76(-5.27,8.79)$ & & $-2.04(-8.81,4.74)$ & & $-0.31(-7.56,6.93)$ & \\
\hline & Missing & $16(14.3 \%)$ & & & & & & \\
\hline
\end{tabular}


Table A3. Cont.

\begin{tabular}{|c|c|c|c|c|c|c|c|c|}
\hline Variable & Category & $\begin{array}{l}\text { No. }(\text { Col \%) of } \\
\text { Children } \\
\text { Taking } \\
\text { Bayley-III Tests }\end{array}$ & $\begin{array}{c}\text { Unadjusted } \\
\text { Estimated Difference } \\
\text { in Language Scores } \\
(95 \% \mathrm{CI})\end{array}$ & $p$ Value $* * *$ & $\begin{array}{c}\text { Unadjusted } \\
\text { Estimated Difference } \\
\text { in Motor Scores }(95 \% \\
\text { CI) }\end{array}$ & $p$ Value $* * *$ & $\begin{array}{c}\text { Unadjusted } \\
\text { Estimated Difference } \\
\text { in Cognitive Scores } \\
(95 \% \mathrm{CI})\end{array}$ & $p$ Value $* * *$ \\
\hline \multirow{4}{*}{$\begin{array}{l}\text { Trimester of pregnancy } \\
\text { with rash }\end{array}$} & First & $25(22.3 \%)$ & (Reference) & \multirow[t]{3}{*}{0.138} & (Reference) & \multirow[t]{3}{*}{0.037} & (Reference) & \multirow[t]{4}{*}{0.523} \\
\hline & Second & $46(41.1 \%)$ & $-0.30(-6.81,6.21)$ & & $-6.25(-12.26,-0.23)$ & & $-0.39(-6.94,6.16)$ & \\
\hline & Third & $23(20.5 \%)$ & $-6.56(-14.13,1.01)$ & & $-8.72(-15.71,-1.73)$ & & $-3.87(-11.48,3.75)$ & \\
\hline & Missing & $18(16.1 \%)$ & & & & & & \\
\hline \multirow{3}{*}{$\begin{array}{l}\text { Smoke during } \\
\text { pregnancy }\end{array}$} & No & $96(85.0 \%)$ & (Reference) & \multirow[t]{3}{*}{1} & (Reference) & \multirow[t]{3}{*}{-0.409} & (Reference) & \multirow[t]{3}{*}{0.944} \\
\hline & Yes & $3(2.7 \%)$ & $0.00(-15.21,15.22)$ & & $-5.63(-19.12,7.86)$ & & $-0.54(-15.87,14.79)$ & \\
\hline & Missing & $14(12.4 \%)$ & & & & & & \\
\hline \multirow{3}{*}{$\begin{array}{l}\text { Drug use during } \\
\text { pregnancy }\end{array}$} & No & $95(84.8 \%)$ & (Reference) & \multirow[t]{3}{*}{0.121} & (Reference) & \multirow[t]{3}{*}{0.797} & (Reference) & \multirow[t]{3}{*}{0.818} \\
\hline & Yes & $3(2.7 \%)$ & $-9.30(-21.09,2.49)$ & & $1.47(-9.86,12.81)$ & & $-1.39(-13.38,10.60)$ & \\
\hline & Missing & $14(12.5 \%)$ & & & & & & \\
\hline \multirow{3}{*}{$\begin{array}{l}\text { Occupational exposure } \\
\text { to toxic products } \\
\text { during pregnancy }\end{array}$} & No & $74(66.1 \%)$ & (Reference) & \multirow[t]{3}{*}{0.735} & (Reference) & \multirow[t]{3}{*}{0.404} & (Reference) & \multirow[t]{3}{*}{0.611} \\
\hline & Yes & $22(19.6 \%)$ & $1.09(-5.26,7.44)$ & & $2.54(-3.49,8.57)$ & & $1.65(-4.78,8.09)$ & \\
\hline & Missing & $16(14.3 \%)$ & & & & & & \\
\hline \multicolumn{9}{|c|}{ Characteristics of household } \\
\hline \multirow{3}{*}{$\begin{array}{l}\text { Monthly income } \\
\text { (relative to minimum } \\
\text { wage) }\end{array}$} & $\begin{array}{c}\text { Classes A, B, C and D: } \\
>2 \times \text { min wage }\end{array}$ & $56(50.0 \%)$ & (Reference) & \multirow[t]{3}{*}{0.169} & (Reference) & \multirow[t]{3}{*}{0.895} & (Reference) & \multirow[t]{3}{*}{0.460} \\
\hline & $\begin{array}{c}\text { Class } \mathrm{E}:<2 \times \text { Min } \\
\text { wage }\end{array}$ & $35(31.3 \%)$ & $-4.03(-9.79,1.74)$ & & $-0.36(-5.84,5.12)$ & & $-2.16(-7.95,3.63)$ & \\
\hline & Missing & $21(18.8 \%)$ & & & & & & \\
\hline \multirow{3}{*}{$\begin{array}{l}\text { Participation in Bolsa } \\
\text { Família }\end{array}$} & No & $78(69.6 \%)$ & (Reference) & \multirow[t]{3}{*}{0.078} & (Reference) & \multirow[t]{3}{*}{0.039} & (Reference) & \multirow[t]{3}{*}{0.019} \\
\hline & Yes & $13(11.6 \%)$ & $-7.05(-14.92,0.81)$ & & $-7.79(-15.20,-0.39)$ & & $-9.42(-17.23,-1.61)$ & \\
\hline & Missing & $21(18.8 \%)$ & & & & & & \\
\hline \multirow{5}{*}{$\begin{array}{l}\text { Household crowding } \\
\text { index }\end{array}$} & $<0.5$ & $31(27.7 \%)$ & (Reference) & \multirow[t]{5}{*}{0.76} & (Reference) & \multirow[t]{5}{*}{0.212} & (Reference) & \multirow[t]{5}{*}{0.280} \\
\hline & $0.5-0.75$ & $33(29.5 \%)$ & $-0.74(-7.33,5.85)$ & & $5.17(-0.99,11.34)$ & & $5.97(-0.66,12.59)$ & \\
\hline & $0.75-1.0$ & $20(17.9 \%)$ & $-0.34(-7.90,7.22)$ & & $0.94(-6.13,8.00)$ & & $3.72(-3.88,11.31)$ & \\
\hline & $1.0+$ & $8(7.1 \%)$ & $-5.57(-16.02,4.89)$ & & $7.89(-1.88,17.65)$ & & $7.22(-3.29,17.72)$ & \\
\hline & Missing & $20(17.8 \%)$ & & & & & & \\
\hline
\end{tabular}

${ }^{*} p$ values do not include missing data categories ${ }^{* *}$ The likelihood ratio test was used to assess the strength of the evidence of an association between exposure variables and outcomes. 


\section{References}

1. Platt, D.J.; Smith, A.M.; Arora, N.; Diamond, M.S.; Coyne, C.B.; Miner, J.J. Zika virus-related neurotropic flaviviruses infect human placental explants and cause fetal demise in mice. Sci. Transl. Med. 2018, 10. [CrossRef] [PubMed]

2. Grant-Klein, R.J.; Baldwin, C.D.; Turell, M.J.; Rossi, C.A.; Li, F.; Lovari, R.; Crowder, C.D.; Matthews, H.E.; Rounds, M.A.; Eshoo, M.W.; et al. Rapid identification of vector-borne flaviviruses by mass spectrometry. Mol. Cell. Probes 2010, 24, 219-228. [CrossRef] [PubMed]

3. Ritchie, S. Dengue Vector Bionomics: Why is Aedes aegypti such a good vector. In Dengue and Dengue Hemorrhagic Fever; CABI: Oxford, UK, 2014.

4. Soares, F.; Abranches, A.D.; Villela, L.; Lara, S.; Araújo, D.; Nehab, S.; Silva, L.; Amaral, Y.; Junior, S.C.G.; Pone, S.; et al. Zika virus infection in pregnancy and infant growth, body composition in the first three months of life: A cohort study. Sci. Rep. 2019, 9, 19198. [CrossRef] [PubMed]

5. Souza, W.V.; Albuquerque, M.; Vazquez, E.; Bezerra, L.C.A.; Mendes, A.; Lyra, T.M.; Araujo, T.V.B.; Oliveira, A.L.S.; Braga, M.C.; Ximenes, R.A.A.; et al. Microcephaly epidemic related to the Zika virus and living conditions in Recife, Northeast Brazil. BMC Public Health 2018, 18, 130. [CrossRef]

6. Netto, E.M.; Moreira-Soto, A.; Pedroso, C.; Höser, C.; Funk, S.; Kucharski, A.J.; Rockstroh, A.; Kümmerer, B.M.; Sampaio, G.S.; Luz, E.; et al. High Zika Virus Seroprevalence in Salvador, Northeastern Brazil Limits the Potential for Further Outbreaks. mBio 2017, 8, e01390-17. [CrossRef]

7. Goldfeld, S.; O'Connor, M.; Cloney, D.; Gray, S.; Redmond, G.; Badland, H.; Williams, K.; Mensah, F.; Woolfenden, S.; Kvalsvig, A.; et al. Understanding child disadvantage from a social determinants perspective. J. Epidemiol. Community Health 2018, 72, 223. [CrossRef]

8. Alderman, H.; Behrman, J.R.; Glewwe, P.; Fernald, L.; Walker, S. Evidence of Impact of Interventions on Growth and Development during Early and Middle Childhood. In Child and Adolescent Health and Development; Bundy, D.A.P., Silva, N., Horton, S., Jamison, D.T., Patton, G.C., Eds.; The International Bank for Reconstruction and Development/The World Bank: Washington, DC, USA, 2017; pp. 79-98.

9. Brasil, P.; Pereira, J.P.; Moreira, M.E.; Ribeiro Nogueira, R.M.; Damasceno, L.; Wakimoto, M.; Rabello, R.S.; Valderramos, S.G.; Halai, U.-A.; Salles, T.S.; et al. Zika Virus Infection in Pregnant Women in Rio de Janeiro. N. Engl. J. Med. 2016, 375, 2321-2334. [CrossRef]

10. Corman, V.M.; Rasche, A.; Baronti, C.; Aldabbagh, S.; Cadar, D.; Reusken, C.B.; Pas, S.D.; Goorhuis, A.; Schinkel, J.; Molenkamp, R.; et al. Assay optimization for molecular detection of Zika virus. Bull. World Health Organ. 2016, 94, 880-892. [CrossRef]

11. Centers for Disease Control and Prevention. Zika MAC-ELISA: Intructions for Use. Available online: https://www.cdc.gov/zika/pdfs/zika-mac-elisa-instructions-for-use.pdf (accessed on 7 April 2020).

12. The Global Health Network (TGHN). INTERGROWTH-21st Global Perinatal Package: The International Fetal and Newborn Growth Consortium for the 21st Century. Available online: https://intergrowth21.tghn.org/ (accessed on 7 April 2020).

13. Alves, L.V.; Paredes, C.E.; Silva, G.C.; Mello, J.G.; Alves, J.G. Neurodevelopment of 24 children born in Brazil with congenital Zika syndrome in 2015: A case series study. BMJ Open 2018, 8, e021304. [CrossRef]

14. Silva, P.F.S.; Eickmann, S.H.; Ximenes, R.A.d.A.; Montarroyos, U.R.; Lima, M.d.C.; Martelli, C.T.; Araújo, T.V.B.d.; Brickley, E.; Rodrigues, L.C.; Gonçalves, F.C.L.P.; et al. Pediatric neurodevelopment by prenatal Zika virus exposure: A cross-sectional study of the Microcephaly Epidemic Research Group Cohort. BMC Pediatr. 2020, 20, 472.

15. Madaschi, V.; Mecca, T.P.; Macedo, E.C.; Paula, C.S. Bayley-III Scales of Infant and Toddler Development: Transcultural Adaptation and Psychometric Properties. Paidéia 2016, 26, 189-197. [CrossRef]

16. Bayley, N. Bayley Scales of Infant and Toddler Development: Administration Manual, 3rd ed.; Psychorp: San Antonio, TX, USA, 2005.

17. Victora, C.G.; Huttly, S.R.; Fuchs, S.C.; Olinto, M.T. The role of conceptual frameworks in epidemiological analysis: A hierarchical approach. Int. J. Epidemiol. 1997, 26, 224-227. [CrossRef]

18. Brazil, F.G.O. Bolsa Família Program: A Decade of Social Inclusion in Brazil. Executive Summary; Institute for Applied Economic Research: Brasília, Brazil, 2014.

19. Ross, E.J.; Graham, D.L.; Money, K.M.; Stanwood, G.D. Developmental Consequences of Fetal Exposure to Drugs: What We Know and What We Still Must Learn. Neuropsychopharmacology 2015, 40, 61-87. [CrossRef] 
20. Campos, M.C.; Dombrowski, J.G.; Phelan, J.; Marinho, C.R.F.; Hibberd, M.; Clark, T.G.; Campino, S. Zika might not be acting alone: Using an ecological study approach to investigate potential co-acting risk factors for an unusual pattern of microcephaly in Brazil. PLOS ONE 2018, 13, e0201452. [CrossRef] [PubMed]

21. Marmot, M. Closing the health gap. Scand. J. Public Health 2017, 45, 723-731. [CrossRef] [PubMed]

22. Kuh, D.; Ben-Shlomo, Y.; Lynch, J.; Hallqvist, J.; Power, C. Life course epidemiology. J. Epidemiol. Community Health 2003, 57, 778. [CrossRef] [PubMed]

23. Lynch, J.; Smith, G.D. A life course approach to chronic disease epidemiology. Annu. Rev. Public Health 2005, 26, 1-35. [CrossRef] [PubMed]

24. Skull, S.A.; Walker, A.C.; Ruben, A.R. Malnutrition and microcephaly in Australian Aboriginal children. Med J. Aust. 1997, 166, 412-414. [CrossRef] [PubMed]

25. Lindsay, S.W.; Wilson, A.; Golding, N.; Scott, T.W.; Takken, W. Improving the built environment in urban areas to control Aedes aegypti-borne diseases. Bull. World Health Organ. 2017, 95, 607-608. [CrossRef] [PubMed]

26. Galobardes, B.; Shaw, M.; Lawlor, D.A.; Lynch, J.W.; Davey Smith, G. Indicators of socioeconomic position (part 1). J. Epidemiol. Community Health 2006, 60, 7-12. [CrossRef]

27. Krauss, M.J.; Morrissey, A.E.; Winn, H.N.; Amon, E.; Leet, T.L. Microcephaly: An epidemiologic analysis. Am. J. Obstet. Gynecol. 2003, 188, 1484-1490. [CrossRef] [PubMed]

28. Silva, A.A.; Barbieri, M.A.; Alves, M.T.; Carvalho, C.A.; Batista, R.F.; Ribeiro, M.R.; Lamy-Filho, F.; Lamy, Z.C.; Cardoso, V.C.; Cavalli, R.C.; et al. Prevalence and Risk Factors for Microcephaly at Birth in Brazil in 2010. Pediatrics 2018, 141. [CrossRef] [PubMed]

29. Krieger, N. Discrimination and health inequities. Int. J. Health Serv. Plan. Adm. Eval. 2014, 44, 643-710. [CrossRef] [PubMed]

30. Carless, W. A Brazilian Student Mapped out Rio's Racial Segregation. What He Found Was Startling. Available online: https://www.pri.org/stories/2015-11-02/brazilian-student-mapped-out-rios-racial-segregation-whathe-found-was-startling (accessed on 7 April 2020).

31. Acevedo-Garcia, D.; Lochner, K.A.; Osypuk, T.L.; Subramanian, S.V. Future directions in residential segregation and health research: A multilevel approach. Am. J. Public Health 2003, 93, 215-221. [CrossRef] [PubMed]

32. Carabali, M.; Austin, N.; King, N.B.; Kaufman, J.S. The Zika epidemic and abortion in Latin America: A scoping review. Glob Health Res Policy 2018, 3, 15. [CrossRef]

33. Pescarini, J.M.; Williamson, E.; Nery, J.S.; Ramond, A.; Ichihara, M.Y.; Fiaccone, R.L.; Penna, M.L.F.; Smeeth, L.; Rodrigues, L.C.; Penna, G.O.; et al. Effect of a conditional cash transfer programme on leprosy treatment adherence and cure in patients from the nationwide 100 Million Brazilian Cohort: A quasi-experimental study. Lancet Infect. Dis. 2020, 20, 618-627. [CrossRef]

34. Pescarini, J.M.; Williamson, E.; Ichihara, M.Y.; Fiaccone, R.L.; Forastiere, L.; Ramond, A.; Nery, J.S.; Penna, M.L.F.; Strina, A.; Reis, S.; et al. Conditional Cash Transfer Program and Leprosy Incidence: Analysis of 12.9 Million Families From the 100 Million Brazilian Cohort. Am. J. Epidemiol. 2020. [CrossRef]

35. Jaitman, L. Urban infrastructure in Latin America and the Caribbean: Public policy priorities. Lat. Am. Econ. Rev. 2015, 24, 13. [CrossRef]

36. Massuda, A.; Hone, T.; Leles, F.A.G.; de Castro, M.C.; Atun, R. The Brazilian health system at crossroads: Progress, crisis and resilience. BMJ Glob. Health 2018, 3, e000829. [CrossRef]

37. Musoke, D.; Boynton, P.; Butler, C.; Musoke, M.B. Health seeking behaviour and challenges in utilising health facilities in Wakiso district, Uganda. Afr. Health Sci. 2014, 14, 1046-1055. [CrossRef]

38. Nielsen-Saines, K.; Brasil, P.; Kerin, T.; Vasconcelos, Z.; Gabaglia, C.R.; Damasceno, L.; Pone, M.; Abreu de Carvalho, L.M.; Pone, S.M.; Zin, A.A.; et al. Delayed childhood neurodevelopment and neurosensory alterations in the second year of life in a prospective cohort of ZIKV-exposed children. Nat. Med. 2019, 25, 1213-1217. [CrossRef] [PubMed]

39. Ximenes, R.A.d.A.; Miranda-Filho, D.d.B.; Brickley, E.B.; Montarroyos, U.R.; Martelli, C.M.T.; Araújo, T.V.B.d.; Rodrigues, L.C.; de Albuquerque, M.d.F.P.M.; de Souza, W.V.; Castanha, P.M.d.S.; et al. Zika virus infection in pregnancy: Establishing a case definition for clinical research on pregnant women with rash in an active transmission setting. PLoS Negl. Trop. Dis. 2019, 13, e0007763. [CrossRef] [PubMed] 
40. Ziraba, A. How Outbreaks Like Ebola Extract Huge Social and Economic Costs. Available online: https: //reliefweb.int/report/world/how-outbreaks-ebola-extract-huge-social-and-economic-costs (accessed on 7 April 2020).

41. Koh, H.K.; Oppenheimer, S.C.; Massin-Short, S.B.; Emmons, K.M.; Geller, A.C.; Viswanath, K. Translating research evidence into practice to reduce health disparities: A social determinants approach. Am. J. Public Health 2010, 100 (Suppl. 1), S72-S80. [CrossRef] [PubMed]

Publisher's Note: MDPI stays neutral with regard to jurisdictional claims in published maps and institutional affiliations.

(C) 2020 by the authors. Licensee MDPI, Basel, Switzerland. This article is an open access article distributed under the terms and conditions of the Creative Commons Attribution (CC BY) license (http://creativecommons.org/licenses/by/4.0/). 